\title{
Variations in Fungal Diversity in a Biochar-Treated Continuous Cotton-Cropped Soil Environment Through Metagenomics-Based Analyses
}

\author{
Guangming Han, Quanqiu Chen, Shengxi Zhang, Guorong Li, Xianda Yi, \\ Changhui Feng, Cui Yu, Jiayang Lan* \\ Industrial Crops Institute of Hubei Academy of Agricultural Sciences/Key Laboratory of Cotton Biology \\ and Breeding in the Middle Reaches of the Changjiang River, Wuhan, Hubei Province
}

Received: 2 September 2019

Accepted: 3 November 2019

\begin{abstract}
Biochar amendment strategy has remained a good alternative for improving soil fertility and alleviating climate change challenges. There exists inadequate information on the role of biochar in influencing soil fungal community structure, especially up to a 40 -year chrono-sequence cropping of plants such as cotton. This study was therefore purposed to determining the soil fungal constituents and their respective diversity in biochar-treated $\left(0 \mathrm{t} \cdot \mathrm{ha}^{-1}, 20 \mathrm{t} \cdot \mathrm{ha}^{-1}\right.$ and $\left.40 \mathrm{t} \cdot \mathrm{ha}^{-1}\right)$ soils of different continuously cotton cropping years $(5,10,20$ and 40 years). The study applied high-throughput sequencing of the the 18S rRNA gene and integrated biostatistics-based techniques to screen the soil fungal community assemblage, key fungal species, soil fungal association structure and metabolic functions, the soil fungal constituents, their proportions and diversity in the biochar-treated cotton pots over the different continuous cropping years. The most abundant fungal phyla were Ascomycota and Basidiomycota. In addition, Aspergillus, a pathogenic fungus, was also detected in all our sequence data. Soil $\mathrm{pH}$ changes were also identified as a key factor in shaping soil fungal communities. Over the continuous cropping duration, the soil $\mathrm{pH}$ gradually declined. At 20 years of continuous cropping, the number of fungal OTU's started to increase and their highest overall quantity was achieved at 20 years of continuous cropping, when $\mathrm{pH}$ was $7.3 \pm 0.1$. Overall, our study findings show that biochar application over a long continuous cropping system alters soil fungal diversity and is therefore an important factor in soil quality management.
\end{abstract}

Keywords: biochar, community structure, continuous cropping, diversity, soil fungi

*e-mail: cottonlab@outlook.com 


\section{Introduction}

Global warming phenomena is already causing serious effects that negatively impact agricultural production all over the globe [1]. Therefore, there is a need for urgent remedial action to strengthen the future of food security for the rapidly expanding human population. A good approach towards that is by finding sustainable mitigation ways to the hindered agricultural sector [2]. The trend in climatic change that is brought about by global warming has resulted in widespread famine conditions in many parts of the world [1]. The sequestration of major nutrients that are key to enhanced crop production are the current key techniques in combating the expanding impacts of global warming and climate change to agricultural productivity [2-3]. Currently, the most preferred nutrient-enhancing techniques are those with minimum interference with soil microbiota such as the ecologically significant fungi [4]. Some of these techniques include the use of inorganic fertilizers such as biochar, which has not only proved to be the best sustainable alternative way of sequestering carbon and other greenhouse gases from the environment but also has promoted soil nutrient quality [5-6]. This has rendered the application of biochar as a form of manure in crop production to be one of the best minimum tillage techniques with positive contributory effects to the soils' beneficial microbes in agricultural farms [7]. Studies by Han et al. [8] reported that continuous long-term biochar application has significantly impacted the diversity of soil bacteria within the cotton farms in China. However, there is still inadequate knowledge on the relationship between longterm biochar application and the soil fungal community within continuously cotton-cropped soil $[5,9]$.

Studies have also shown that the improvement of soil nutrient contents such as iron $(\mathrm{Fe})$ and molybdenum (Mo) properties in agricultural farmlands highly depend on the inter and intra relationship between the different soil bacteria and fungi [4-5]. Most endophytic fungus have the ability to support ecosystem services through symbiotic relationships with the host and the abiotic environment, and such relationships can enhance the acquisition of important soil nutrients such as nitrogen. However, there is inadequate understanding regarding how the fungus influence soil properties and microbial communities [5, 9]. [5] reported that the mechanism of plant-soil feedback may be mediated by the plantfungus interaction such as rice-endophyte interactions, especially in soils with nutrient limitations. Proper understanding of the impact of long-term biochar application to the soil beneficial fungal community is essential for promoting the production of essential agricultural products, especially in regions like China where the large human population has continued to add pressure to deteriorating agricultural produce $[3,7]$. The few existing studies that have focused on the effects of biochar application on the soil microbial community assemblage have widely considered the influence of long-term continuous biochar application (more than 20 years) on the bacterial community rather than on the fungal community [8]. Furthermore, the majority of these studies have not interpretively applied the highly reliable modern bioinformatic and biostatistical techniques in assessing either the availability of bacterial or fungal community and soil quality on longterm (up to 40 years) biochar application $[2,8,10]$.

Our study hypothesized that there was no difference in the soil fungal community assemblage, key fungal species, soil fungal association structure and metabolic functions, soil fungal constituents, their proportions and diversity between the varied duration of cotton cropping years and different fertilizer application rates. Therefore, the current study investigated the impact of the application of biochar as a soil treatment additive in a varied duration of cotton cropping years $(5,10,20$ and 40 years) and application rates $\left(0 \mathrm{t} \cdot \mathrm{ha}^{-1}, 20 \mathrm{t} \cdot \mathrm{ha}^{-1}\right.$ and $\left.40 \mathrm{t} \cdot \mathrm{ha}^{-1}\right)$ to the soil fungal community structure. The study applied high-throughput sequencing of the 18S rRNA gene and integrated biostatisticalbased techniques to screen the soil fungal community assemblage, key fungal species, soil fungal association structure and metabolic functions, the soil fungal constituents, their proportions and diversity in the biochar-treated cotton pots over the different continuous cropping years. This study aimed to provide a highly reliable inference on the response of soil fungal community to the application of biochar in cotton soils with different continuous cropping years and application rates using the integrated bioinformatic analyses approach.

\section{Materials and Methods}

\section{Experimental Study Site and Cotton Variety}

The study was designed in an experimental farm owned by Xinjiang Jin B Seed Centre in Bole City, Xinjiang, China (GPS coordinates: $44^{\circ} 46^{\prime} 56.0^{\prime \prime} \mathrm{N} 82^{\circ} 23^{\prime} 57.0^{\prime \prime} \mathrm{E}$ ). The study site is located in the northwestern part of Xinjiang, which neighbors Kazakhstan. Xinjiang's regional climate is a local steppe climate. Bole is a continental arid semi-desert and desert climate with long sunshine hours and large temperature differences between day and night. The temperature in spring is warm and cold, summer is hot, the climate is hot, with dry and hot winds, autumn is cool, winter is long and cold, the annual average temperature is $5.6^{\circ} \mathrm{C}$, average annual precipitation is 181 $\mathrm{mm}$, and annual average evaporation is $1562.4 \mathrm{~mm}$. The extreme maximum temperature is $44^{\circ} \mathrm{C}$ and the extreme minimum temperature is $-36^{\circ} \mathrm{C}$. The annual average sunshine hours are 2815.8, accumulated temperature of $\geq 10^{\circ} \mathrm{C}$ is $3137.9^{\circ} \mathrm{C}$, and the frost-free period is 169 days. Bole has good light, heat and water elements, and is suitable for planting a variety of agricultural and melon crops. 
Table 1. Treatment/Sample labels.

\begin{tabular}{|c|c|c|c|c|c|c|c|c|c|}
\hline \multirow{2}{*}{ Years } & \multicolumn{3}{|c|}{$0 \mathrm{t} \cdot \mathrm{ha}^{-1}$} & \multicolumn{3}{|c|}{$20 \mathrm{t} \cdot \mathrm{ha}^{-1}$} & \multicolumn{3}{c|}{$40 \mathrm{t} \cdot \mathrm{ha}^{-1}$} \\
\cline { 2 - 11 } & Rep 1 & Rep2 & Rep3 & Rep 1 & Rep2 & Rep3 & Rep 1 & Rep2 & Rep3 \\
\hline 5 & AT01 & AT02 & AT03 & AT11 & AT12 & AT13 & AT21 & AT22 & AT23 \\
\hline 10 & BT01 & BT02 & BT03 & BT11 & BT12 & BT13 & BT21 & BT22 & BT23 \\
\hline 20 & CT01 & CT02 & CT03 & CT11 & CT12 & CT13 & CT21 & CT22 & CT23 \\
\hline 40 & DT01 & DT02 & DT03 & DT11 & DT12 & DT13 & DT21 & DT22 & DT23 \\
\hline
\end{tabular}

\section{Soil and Biochar Fertilizer}

Soil samples were obtained from the top layer (0-15 cm depth) of cotton farm plots that had been continuously cropped at time intervals of 5,10 , 20 and 40 years under constant culturing and soil management. Based on Food Agriculture Organization (FAO) classification guidelines, the soil samples were categorized as acrisols with $66 \%$ clay content. Mineral fertilizers (NPK) used in these field tests were full element compound fertilizer. The total nutrient content is $45 \%$, of which the total nitrogen content is $15 \%$, available phosphorus content is $15 \%$, and available potassium content is $15 \%$. Biochar is a pyrolysis of farmland waste at high temperature $\left(550^{\circ} \mathrm{C}\right)$. It does not have microbial activity itself, but it can provide a micro-environment for soil microbes and some carbon sources for microbial utilization. Biochar was made out of corncob feedstock using a traditional kiln reactor (Fengben Biological Technology Co., Ltd, Shandong, China) at a rising heating gradient of $10^{\circ} \mathrm{C} \mathrm{min}^{-1}$ up to $550^{\circ} \mathrm{C}$. Firstly, the corncob feedstock was air-dried before being pyrolyzed under controlled conditions. Total carbon and nitrogen were established through combustion analysis (vario Macro CNS; Elementar, Germany). Ammonium $\left(\mathrm{NH}^{+}\right)$and nitrate $\left(\mathrm{NO}^{3-}\right)$ evaluations were performed through extraction with $0.5 \mathrm{M} \mathrm{K}_{2} \mathrm{SO}_{4}$ and colorimetrical analysis of $\mathrm{NH}^{4+}$, and thereafter the extracts of $\mathrm{NO}^{3-}$ were established using an automated flow injection by means of a Skalar autoanalyzer (Skalar San Plus). Carbonate equivalence assessment was performed as depicted by Rayment and Lyon. Electrical conductivity (EC) and $\mathrm{pH}$ were determined in a 1:5 $\left(\mathrm{w} / \mathrm{v} ; \mathrm{g} \mathrm{cm}^{-3}\right)$ soil:water environment and in $0.01 \mathrm{M} \mathrm{CaCl}_{2}$ mixtures. The basic chemical properties of the soil and biochar are described in Table 2.

\section{Experimental Design and Cotton Variety}

Different continuously cotton-cropped research fields $(5,10,20$ and 40 years), each with measurements of $100 \mathrm{~m}^{2}$, were selected and marked for the study. Initial field preparation entailed removal of pebbles, stones and plant debris. Thereafter, appropriate calculated portions of the biochar were mixed in the field plots, with respective biochar application rates of $0 \mathrm{t} \cdot \mathrm{ha}^{-1}, 10 \mathrm{t} \cdot \mathrm{ha}^{-1}$ and $20 \mathrm{t} \cdot \mathrm{ha}^{-1}$. In total, each of the four continuous cropped plots had three biochar application rates, resulting in 12 treatments. Each treatment was done in triplicate, leading to a total of 36 experimental plots $(4 \times 3 \times 3=36)$ as shown in Table 1. A similar quantity of initial compound fertilizer (N:P:K = 15:15:15) was applied to all the plots. The cotton variety used in this study is Xinluzao 80, which has the characteristics of early maturity, high quality and suitability for mechanical harvesting. The growth period is 117 days, plant height is $75 \mathrm{~cm}$, pre-frost flower rate is $95.6 \%$, clothing fraction is $43 \%$, the upper half of the fiber is $30.0 \mathrm{~mm}$, specific strength is $31.4 \mathrm{cN} /$ tex, micronaire value is 4.7 , and uniformity index is $85.3 \%$. The average yield of lint cotton per

Table 2. Basic chemical properties of biochar and soil.

\begin{tabular}{|c|c|c|c|c|c|}
\hline \multirow{2}{*}{ Chemical Properties } & \multirow{2}{*}{ Biochar } & \multicolumn{4}{|c|}{ Contiuous cropped soil } \\
\cline { 3 - 6 } & & 5 Years & 10 Years & 20 Years & 40 Years \\
\hline Total $\mathrm{N}\left({\left.\mathrm{g} \cdot \mathrm{kg}^{-1}\right)}^{2}\right.$ & 2.7 & $1.51 \pm 0.02^{\mathrm{a}}$ & $1.23 \pm 0.02^{\mathrm{b}}$ & $1.01 \pm 0.02^{\mathrm{c}}$ & $0.93 \pm 0.05^{\mathrm{c}}$ \\
\hline $\mathrm{NH}_{4}^{+}\left(\mathrm{mg} \cdot \mathrm{kg}^{-1}\right)$ & $<0.1$ & $16.2 \pm 0.1^{\mathrm{a}}$ & $14.1 \pm 0.1^{\mathrm{b}}$ & $12.2 \pm 0.1^{\mathrm{c}}$ & $10.8 \pm 0.1^{\mathrm{c}}$ \\
\hline $\mathrm{NO}_{3}^{-}\left(\mathrm{mg} \cdot \mathrm{kg}^{-1}\right)$ & $<0.2$ & $2.4 \pm 0.1^{\mathrm{a}}$ & $2.4 \pm 0.0^{\mathrm{a}}$ & $1.9 \pm 0.1^{\mathrm{b}}$ & $1.80 \pm 0.1^{\mathrm{b}}$ \\
\hline Total C $\left(\mathrm{g}^{\mathrm{b}} \mathrm{kg}^{-1}\right)$ & 680.0 & $11.5 \pm 0.3^{\mathrm{a}}$ & $10.2 \pm 0.2^{\mathrm{b}}$ & $10.1 \pm 0.1^{\mathrm{b}}$ & $10.0 \pm 0.2^{\mathrm{b}}$ \\
\hline $\mathrm{pH}\left(\mathrm{CaCl}_{2}\right)$ & 8.3 & $8.3 \pm 0.3^{\mathrm{a}}$ & $8.1 \pm 0.4^{\mathrm{ab}}$ & $7.6 \pm 0.1^{\mathrm{b}}$ & $7.3 \pm 0.1^{\mathrm{b}}$ \\
\hline $\mathrm{EC}\left(\mu \mathrm{S} \cdot \mathrm{cm}^{-1}\right)$ & 526.3 & $43.3 \pm 1.8^{\mathrm{a}}$ & $43.1 \pm 1.6^{\mathrm{a}}$ & $40.8 \pm 2.0^{\mathrm{a}}$ & $37.8 \pm 2.7^{\mathrm{b}}$ \\
\hline
\end{tabular}

The data are expressed as mean $\pm \mathrm{SD}(\mathrm{n}=3)$. Superscript letters that differ within rows indicate significant differences between treatments $(\mathrm{p}<0.05)$. 
hectare is $1830-22$. Cotton seedling sowing was done on 15 April 2017 at a planting gap of $10 \times 50 \mathrm{~cm}$. Constant weeding was manually conducted whenever necessary during the experiment. Watering of the plots was also done whenever necessary.

\section{Soil Sampling}

Soil sampling in all the treatments was performed at the boll-opening stage on $25^{\text {th }}$ July 2017. Briefly, the soils samples were randomly collected in replicates of 10 in a range of $5 \mathrm{~cm}$ from the cotton trunk at soil depths of $0-15 \mathrm{~cm}$. Thereafter, all the replicates were mixed to produce homogenous sample. They were transported to the lab in cold-chain and all the physico-chemical parameters analyzed within a week from the collection time. One part of all study samples was cryopreserved $\left(-80^{\circ} \mathrm{C}\right)$ for later use in soil microbiological and chemical analysis.

\section{DNA Extraction and PCR Amplification of $18 \mathrm{~S}$ rRNA}

Genomic DNA was extracted from the soil samples using an E.Z.N.A. soil DNA kit (Omega BioTec, Inc., USA) as per the manufacturer's guidelines. The obtained DNA was assessed by loading $10 \mu \mathrm{L}$ of the samples and running them on $1 \%$ agarose gel. The barcoded fusion primers (forward primers: 341F: CCTACACGACGCTCTTCCGATCTNCCTAC GGGNGGCWGCAG, reverse primers: 805R G A C T G G A G T T C C T T G G C A C C C G A G A A TTCCAGACTACHVGGGTATC-TAATCC) were used in the amplification of the $\mathrm{V} 3-\mathrm{V} 4$ hypervariable regions of $16 \mathrm{~S}$ rRNA via PCR from the microbial genomic DNA. The PCR reaction mixture $(50 \mu \mathrm{l})$ comprised of $5 \mu \mathrm{l}$ of $10 \times$ PCR reaction buffer (TakaRa, Japan), $10 \mathrm{ng}$ of DNA template, $0.5 \mu \mathrm{l}$ of each primer, $0.5 \mu \mathrm{l}$ of dNTPs and $0.5 \mu \mathrm{l}$ of Platinum Taq DNA polymerase (TakaRa, Japan). Thermocycler amplification conditions were set at: initial $94^{\circ} \mathrm{C}$ for $3 \mathrm{~min}, 94^{\circ} \mathrm{C}$ for $30 \mathrm{~s}$, annealing at $45^{\circ} \mathrm{C}$ for $20 \mathrm{~s}$ and $65^{\circ} \mathrm{C}$ for $30 \mathrm{~s}$, which was repeated for 5 cycles, followed by $94^{\circ} \mathrm{C}$ for $20 \mathrm{~s}, 55^{\circ} \mathrm{C}$ for $20 \mathrm{~s}$ and $72^{\circ} \mathrm{C}$ for $30 \mathrm{~s}$, which was repeated for 20 cycles, before a final elongation at $72^{\circ} \mathrm{C}$ for $5 \mathrm{~min}$. Specificity assessment of the PCR amplification product was assessed on $1.5 \%$ agarose gel and thereafter purified using a QIAquick Gel Extraction Kit.

\section{Illumina Sequencing and Data Processing}

Paired-end sequencing was conducted using an Illumina MiSeq (Illumina, San Diego, CA, USA) system. Sequencing amplicons were barcoded into two (V3 and V4 amplicon). Quality check was performed on the sequence data and poor-quality reads were cut off using Prinseq software (PRINSEQ-lite 0.19.5). The V3 and V4 paired-end reads were assembled with respect to a 10 -base pair reads overlap with no mismatch via
Flash software (FLASH v1.2.7), and afterwards the non-assembled reads were discarded. Uclust software (Uclust v1.1.579) was used to cluster sequences and assign them to operational taxonomic units (OTUs) at a $3 \%$ dissimilarity level. Assigning of taxonomic ranks to each sequence was done using the Ribosomal Database Project (RDP) Naïve Bayesian Classifier v.2.2 trained on the green genes database (October 2012 version).

\section{Classification and Taxonomic Status Identification}

Orthogonal taxonomic units (OTU) status and identification was achieved by using QIIME software that compared the OTU representative sequence to the template sequence of the corresponding database to get the taxonomic information corresponding to each OTU. Each specific database is used as the template sequence of OTU classification status identification for different categories of sequences. The phylogenetic and taxonomic trees were constructed on MEGAN software (http://ab.inf.uni-tuebingen.de/software/megan6/), which involved mapping the abundance information of OTU and Taxonomy composition data contained in each sample to the microbial taxonomy hierarchy tree provided by the NCBI website (https://www.NCBI.nlm. nih.gov/Taxonomy) to present the concrete composition of all samples at each classification level in a standard classification hierarchy. A comparative analysis was done through GraPhlAn and Krona software.

\section{Community Diversity and Taxonomic Composition}

Community diversity was calculated through Chao 1, Ace, Shannon and Simpson indices using QIIME software. The specific composition of each sample at genus level was calculated based on the results on OTU classification and taxonomic status identification.

\section{Screening of Key Species}

This was carried out through principal component analysis (PCA) and multi-dimensional scaling analysis (MDA). PCA was used to analyze the community composition structure at the genus level, and the natural distribution between the samples was described with two-dimensional and three-dimensional images by $\mathrm{R}$ software. The unweighted pair group method with arithmetic means (UPGMA) was used in MDA using QIIME software. Comparative analysis of bacteria and screening of key species was done through PLS-DA (partial least squares discriminant analysis).

\section{Cluster Distribution and Prediction of Microbial Metabolic Function}

The number of unique and shared functional group was calculated by $\mathrm{R}$ software through Venn graph 


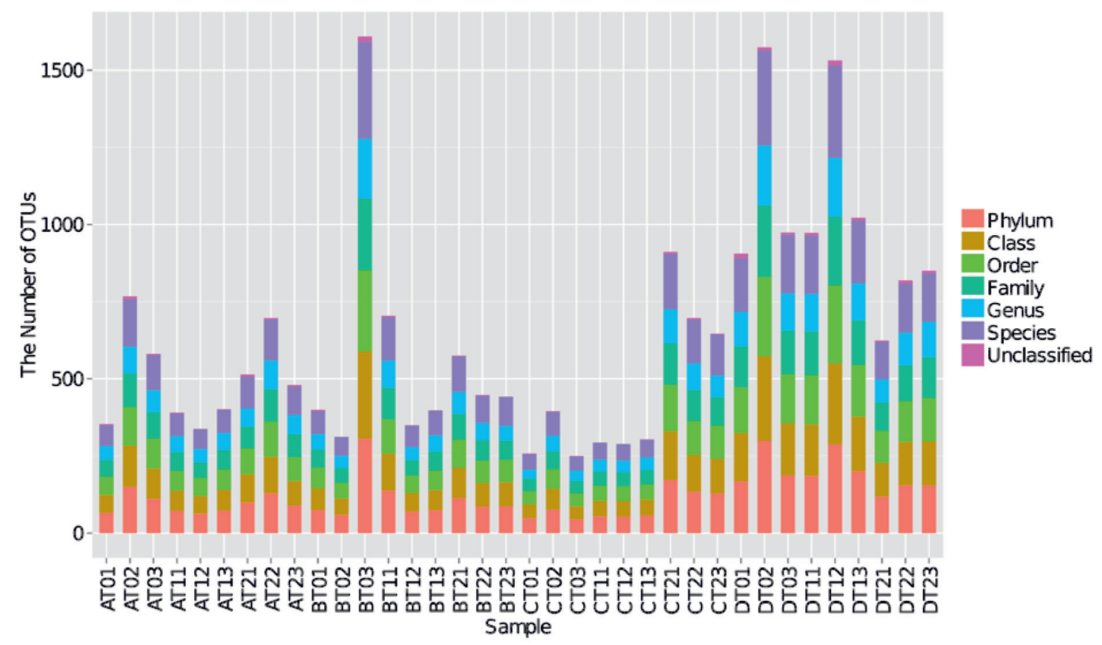

Fig. 1. OTU abundance in the generated sequences.

analysis. Phylogenetic investigation of communities by reconstruction of unobserved states (PICRUST) was used in predicting the significant microbial metabolic functions using the KEGG database (http://www. genome.jp/kegg/pathway.html).

\section{Statistical Data Analysis}

Data was analyzed using SPSS, QIIME and R software. Mean differences were calculated at a $p$ value of 0.05. Significant differences among the means were determined using the LSD test. T-tests and metastats (http://metastats.cbcb.umd.edu/) in Mothur were used to compare the differences, and all p-values were adjusted with the false discovery rate (FDR) using the $\mathrm{BH}$ method with the mt.rawp2adjp function in $\mathrm{R}$.

\section{Results and Discussion}

Soil physicochemical properties including total $\mathrm{N}\left(\mathrm{g} \cdot \mathrm{kg}^{-1}\right), \mathrm{NH}_{4}^{+}\left(\mathrm{mg} \cdot \mathrm{kg}^{-1}\right), \quad \mathrm{NO}^{3-}\left(\mathrm{mg} \cdot \mathrm{kg}^{-1}\right)$, total $\mathrm{C}$
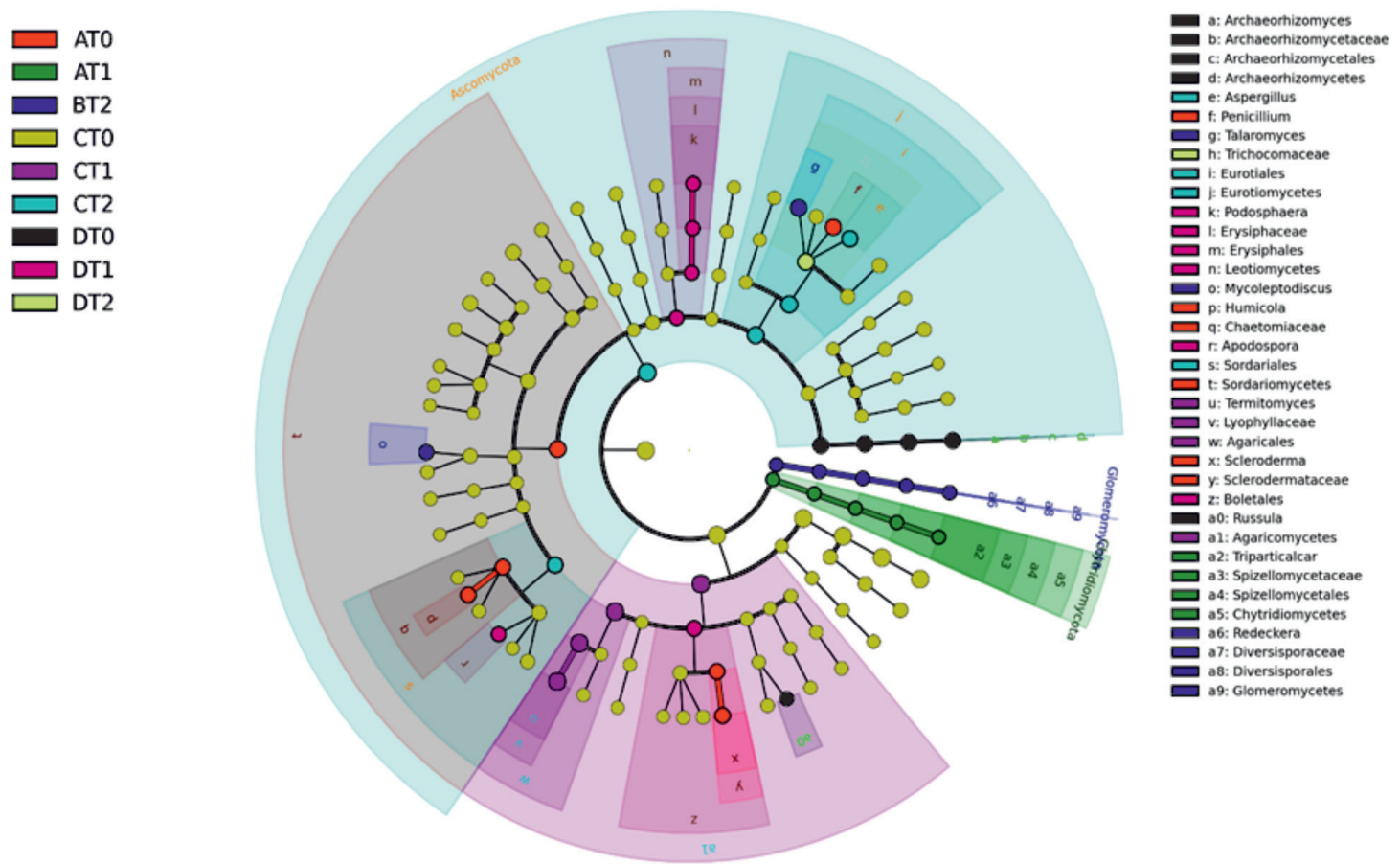

Fig. 2. Cladogram indicating the phylogenetic distribution of fungal lineages under the fertilization regimes, with each circle's diameter proportional to the given taxon's relative abundance; differences are represented in the color of the highest abundant taxa (AT0, AT1, BT2, CT0, CT1, CT2, DT0, DT1, and DT2 are all indicated with varying colors). 

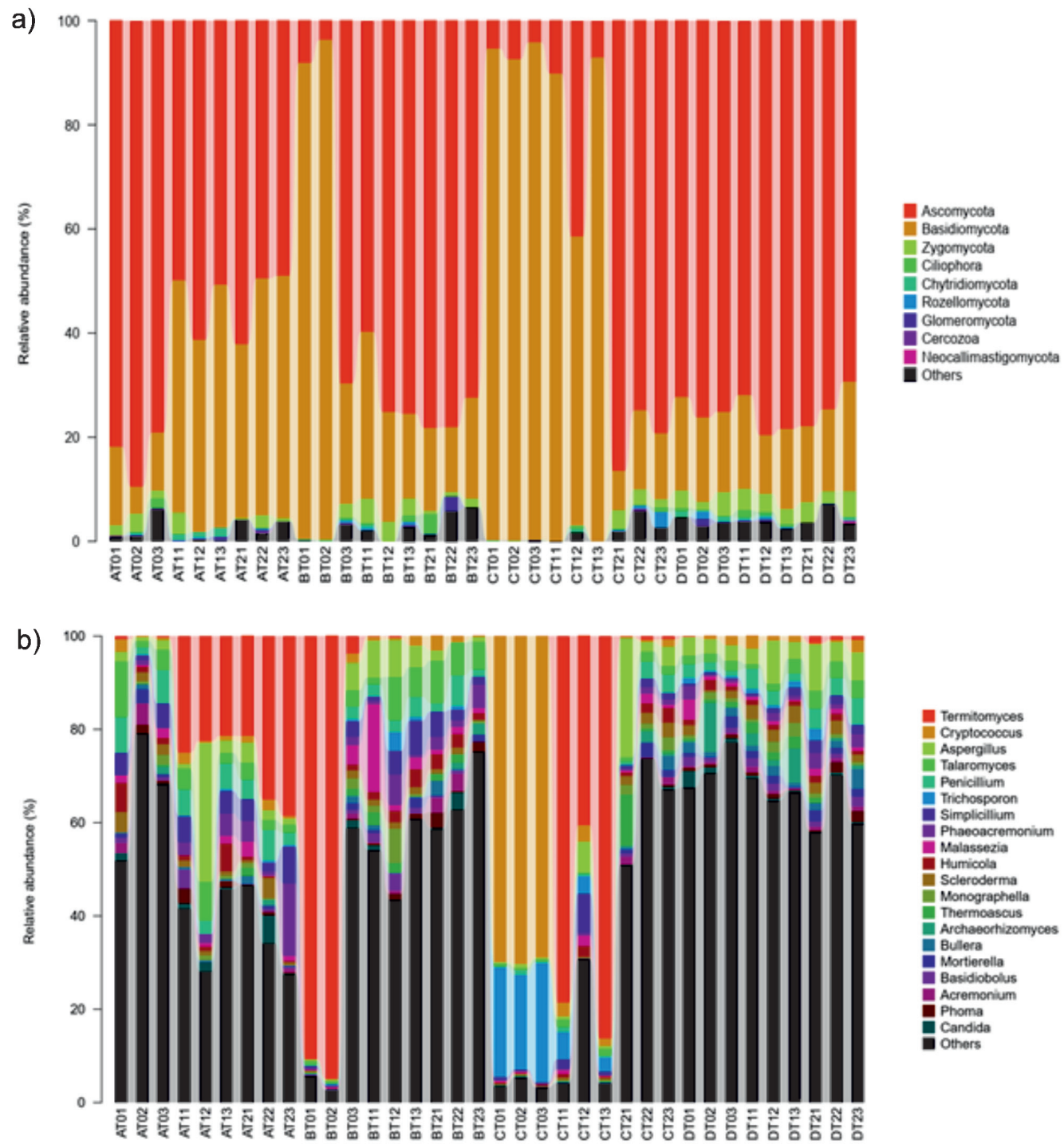

Fig. 3. Relative abundances of fungal phyla a) and genera b) under different fertilizer treatment regimens.

$\left(\mathrm{g} \cdot \mathrm{kg}^{-1}\right), \mathrm{pH}\left(\mathrm{CaCl}_{2}\right)$ and $\mathrm{EC}\left(\mu \mathrm{S} \cdot \mathrm{cm}^{-1}\right)$ were all tested and results are represented in Table 2. A total of 1,662,207 reads with an average length of $300 \mathrm{bp}$ were obtained after Miseq Illumina sequencing. Using QIIME, a total of 4339 OTU's were generated, with 97\% identity as the cutoff. BT03, DT02 and DT12 were the three most abundant OTU's (Fig. 1 and Supplementary Fig. 1). Furthermore, a considerably higher number of OTU's was in DT01, DT01, DT02, DT03, DT11, DT12, DT13, DT21, DT22 and DT23 - all which fall on 40 years of continuous cotton cropping. Using a GraPhlAn toolkit, hierarchical tree on taxonomic composition and abundance distribution of the soil mycobiome was generated (Fig. 2). Ascomycota was the most dominant fungus phyla, followed by Basidiomycota. Furthermore, under Ascomycota, Sordariomycetes, Dothideomycetes and Eurotiomycetes were the top three most dominant groups while Agaricomycetes and Tremellomycetes were the most abundant groups under Basidiomycota (Fig. 2).
Through QIIME, Chao 1, ACE and Shannon indices was used to assess the alpha diversity of the microbial communities present in the soil samples used in this present study (Table 3). In brief, Chao 1 and Ace indices quantify the microbial community richness, whereas Shannon and Simpson indices give more sensitivity to the microbial richness together with rare OTU's and microbial evenness in addition to dominance. Fungal richness and diversity continuously increased with respect to more addition of biochar (Table 3). The characterized sequences for each fertilizer treatment were associated with the dominant fungal phyla: Ascomycota, Basidiomycota and Zygomycota were the leading group in almost all the fertilizer treatments. Specifically, Ascomycota was the most predominant group in DT01 to DT23 treatments, while other remaining sequences were associated with other less dominant fungal phyla (Fig. 3a). The main genera across all the treatment groups were Termitomyces, Cryptococcus, Aspergillus and Talaromyces, among 
Table 3. Diversity index values by Chao 1, ACE, Simpson and Shannon methods for every fertilizer treatment.

\begin{tabular}{|c|c|c|c|c|c|c|c|c|c|}
\hline \multirow{2}{*}{$\begin{array}{l}\text { Years/ } \\
\text { Indices }\end{array}$} & \multicolumn{3}{|c|}{$0 \mathrm{t} \cdot \mathrm{ha}^{-1}$} & \multicolumn{3}{|c|}{$20 \mathrm{t} \cdot \mathrm{ha}^{-1}$} & \multicolumn{3}{|c|}{$40 \mathrm{t} \cdot \mathrm{ha}^{-1}$} \\
\hline & $\operatorname{Rep} 1$ & Rep2 & Rep3 & $\operatorname{Rep} 1$ & Rep2 & Rep3 & $\operatorname{Rep} 1$ & Rep2 & Rep3 \\
\hline 5 & AT01 & AT02 & AT03 & AT11 & AT12 & AT13 & AT21 & AT22 & AT23 \\
\hline Chao 1 & 72.00 & 163.43 & 119.00 & 75.43 & 65.50 & 76.11 & 110.33 & 138.17 & 97.00 \\
\hline $\mathrm{ACE}$ & 72.08 & 163.54 & 119.90 & 76.43 & 66.21 & 76.78 & 111.13 & 138.58 & 97.00 \\
\hline Simpson & 0.96 & 0.76 & 0.98 & 0.91 & 0.86 & 0.92 & 0.93 & 0.87 & 0.83 \\
\hline Shannon & 5.23 & 4.19 & 6.03 & 4.47 & 3.88 & 4.54 & 5.09 & 4.99 & 4.07 \\
\hline 10 & ВT01 & ВT02 & ВT03 & BT11 & BT12 & BT13 & BT21 & BT22 & BT23 \\
\hline Chao 1 & 80.31 & 64.00 & 334.47 & 146.67 & 71.60 & 81.50 & 120.50 & 94.33 & 94.86 \\
\hline ACE & 81.91 & 65.68 & 333.69 & 147.97 & 72.11 & 81.78 & 120.63 & 93.71 & 96.18 \\
\hline Simpson & 0.18 & 0.10 & 0.98 & 0.97 & 0.96 & 0.97 & 0.97 & 0.98 & 0.97 \\
\hline Shannon & 0.95 & 0.56 & 7.06 & 6.17 & 5.04 & 5.64 & 5.84 & 5.79 & 5.66 \\
\hline 20 & СT01 & СТ02 & СТ03 & CT11 & CT12 & CT13 & СТ21 & СТ22 & СТ23 \\
\hline Chao 1 & 52.60 & 79.11 & 47.00 & 56.25 & 57.11 & 59.25 & 185.60 & 150.50 & 135.00 \\
\hline $\mathrm{ACE}$ & 52.97 & 79.49 & 47.20 & 57.00 & 60.26 & 59.50 & 185.52 & 151.02 & 135.35 \\
\hline Simpson & 0.46 & 0.47 & 0.46 & 0.38 & 0.80 & 0.26 & 0.92 & 0.98 & 0.98 \\
\hline Shannon & 1.47 & 1.71 & 1.40 & 1.63 & 3.41 & 1.21 & 5.26 & 6.26 & 6.26 \\
\hline 40 & DT01 & DT02 & DT03 & DT11 & DT12 & DT13 & DT21 & DT22 & DT23 \\
\hline Chao 1 & 190.20 & 320.15 & 197.30 & 199.67 & 318.36 & 221.55 & 126.00 & 169.38 & 165.00 \\
\hline $\mathrm{ACE}$ & 190.09 & 319.48 & 198.07 & 200.41 & 318.09 & 218.13 & 126.28 & 170.03 & 165.27 \\
\hline Simpson & 0.98 & 0.99 & 0.98 & 0.99 & 0.98 & 0.98 & 0.98 & 0.99 & 0.99 \\
\hline Shannon & 6.63 & 7.26 & 6.73 & 6.94 & 6.95 & 6.53 & 6.16 & 6.68 & 6.74 \\
\hline
\end{tabular}

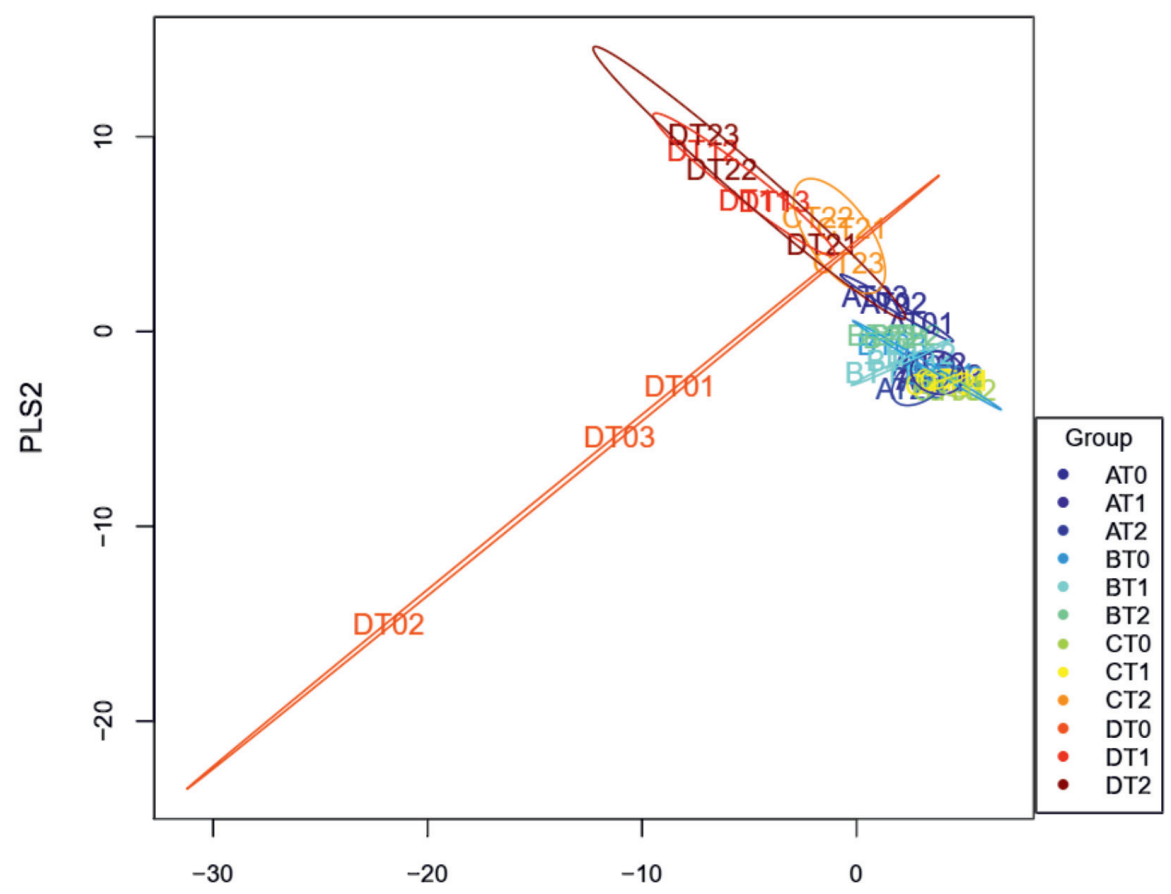

PLS1

Fig. 4. PLS-DA discriminant analysis chart. 
others (Fig. 3b). The partial least squares discriminant analysis (PLS-DA) indicated that AT0, AT1, AT2, BT0, BT1, BT2, CT0, Ct1 and CT2 scattered closely on the right, whereas the DT01, DT02 and DT03 groups scattered diagonally across the $\mathrm{x}$ and $\mathrm{y}$ axis (Fig. 4). There was an overlap observed between the DT and CT groups, while also a second overlap and cluster was seen in the At and BT groups, indicating a similarity degree of fungal diversity between the groups.

Generally, soil harbors diverse microbiome. This microbiome structure and diversity varies from one environ to another. This variation state of soil community structure can be influenced by the type of soil [11-12], soil $\mathrm{pH}$ [13-16], environmental climate [7, 17], soil electrical conductivity (EC) $[13,18]$, nutrient availability [19] and plant diversity [20]. Equally, soil microbiome has been linked to playing a significant part in defining some soil functions such as nitrogen (N) mineralization, carbon (C) turnover rate and pest control [21-23]. Biochar, a pyrolysis product of organic material, has got extensive interest as a way to enhance soil nutrient availability and subsequently improve crop productivity. Based on various previously conducted studies, soil biochar treatments have been shown to improve soil microbial communities by enriching the physical and chemical characteristics of the soil [2426], providing conducive habitats for microorganisms against predators [27], contributing labile C substrates for degradation [28-29], boosting macronutrient availability such as $\mathrm{N}$ and $\mathrm{P}[25,30]$, or even adsorbing compounds that would hinder microbial growth [31].

All along the chrono-sequence age, variations in the soil fungi types was apparent at taxonomic levels. Our findings demonstrate that the application of biochar on continuously cropped cotton soils (5,10,20 and 40 years) significantly altered soil myco-biota communities. From Chaol and ACE indices, our results indicate that continuous and quantity increase of biochar in cropped cotton soil treatment significantly increased the fungal richness (Table 1). Previously conducted studies have reported on the positive effect of organic matter application in cropped soils through improvement of soil $\mathrm{pH}$, organic $\mathrm{C}$ and the major soil nutrients of $\mathrm{N}$, $\mathrm{P}$ and $\mathrm{K}$ [32]. Sequence analyses of our data revealed that the dominant recovered fungal sequences were the phyla Ascomycota and Basidiomycota (Figure 2a). The relative predominance of Ascomycota (57.9\%) was higher in fields with continous high biochar quantity treatment compared to fields with lower treatment quantities, while for Basidiomycota (36.5\%) it was less. In agreement with our results, the majority of saprotrophic microfungi are Ascomycota and their growth tempo is associated with the availability of nitrogen [14, 33]. Basidiomycetes are generally identified as lignin decomposers, hence they are vital for soil carbon cycling [34]. Furthermore, a study conducted by Schadt et al. also identified a large percentage of Ascomycota as the most common fungal sequences in tundra soils [35]. In addition, Aspergillus, a pathogenic fungus, was also detected in all our treatments (Fig. 3b). Aspergillus is a known plant pathogen responsible for various plant rot cases [36]. Since fungal species vary with respect to their $\mathrm{pH}$ tolerance, soil $\mathrm{pH}$ changes could shape fungal community composition. Over the continuous cropping duration, the soil $\mathrm{pH}$ gradually declined (Table 2). At 20 years of continuous cropping, the number of fungal OTU's started to increase and their highest overall quantity was achieved at 20 years of continuous cropping when the $\mathrm{pH}$ was $7.3 \pm 0.1$. Our findings are in line with previously conducted studies that have described the association of higher fungal diversity increases to a declining soil $\mathrm{pH}$ gradient [37].

\section{Conclusion}

This work highlights results on changes of soil fungi during long continuous cropping patterns, specifically for cotton as the crop of use. Our findings demonstrate that the application of biochar on continuously cropped cotton soils $(5,10,20$ and 40 years $)$ significantly altered soil fungal communities. The most abundant fungal phyla were Ascomycota and Basidiomycota. In addition, Aspergillus, a pathogenic fungus responsible for various plant diseases, was also detected in all our sequence data. Soil $\mathrm{pH}$ changes were also identified as a key factor in shaping soil fungal communities. Over the continuous cropping duration, the soil $\mathrm{pH}$ gradually declined. At 20 years of continuous cropping, the number of fungal OTU's started to increase and their highest overall quantity was achieved at 20 years of continuous cropping, when the $\mathrm{pH}$ was $7.3 \pm 0.1$. Overall, our study findings show that biochar application over a long continuous cropping system alters soil fungal diversity.

\section{Acknowledgements}

This study was supported by the National Natural Science Foundation of China (Grant No. 31671636), the National Key Research and Development Program (Grant No. 2016YFD0101408) and the Agricultural Science and Technology Innovation Center of Hubei Province (Grant No. 2016-620-000-001-010)

\section{Conflict of Interest}

The authors declare that there is no conflict of interest between them or their various institutions.

\section{References}

1. AMARE A., SIMANE B. Determinants of smallholder farmers' Decision to adopt adaptation options to climate change and variability in the Muger sub basin of the upper 
Blue Nile basin of Ethiopia. Agriculture \& Food Security. 6 (64), 2017.

2. PIASH M.I., FARUQUE H., IHUOMA N.A., SHAMIM A.M., ZAKIA P. Effect of biochar application on soil carbon fluxes from sequential dry and wet cultivation systems. American Journal of Climate Change. 07 (01), 40, 2018. doi:10.4236/ajcc. 2018.71005

3. ZHANG D., HUANG X., WANG Z., HUANG Y. The Performance and Carbon Sequestration of the Biochar concrete. Advances in Environmental Protection. 7 (6), 465, 2017.

4. CHUN L S., FENG M.Z., KAI S., WEI Z., CHUAN C.D. Fungal endophyte Phomopsis liquidambari improves Iron and Molybdenum nutrition uptake of peanut in consecutive monoculture soil. Journal of Soil Science and Plant Nutrition. 19, 71, 2019.

5. YANG B., WANG X.M., MA H.Y., YANG T., JIA Y., ZHOU J. DAI C.C. Fungal endophyte Phomopsis liquidambari affects nitrogen transformation. processes and related microorganisms in the rice rhizosphere. Front Microbiol. 6, 982. 2015.

6. PACHAURI R.K., LEO M. Climate Change 2014: Synthesis Report. Intergovernmental Panel on Climate Change. Accessed June 5, 2018. http://epic.awi.de/37530/.

7. ZHOU Z., CHANGWEN D., TING L., YAZHEN S., YIN Z., JIE D., JIANMIN Z. Biodegradation of a biocharmodified waterborne polyacrylate membrane coating for Controlled-Release Fertilizer and Its Effects on Soil Bacterial Community Profiles. Environmental Science and Pollution Research. 22 (11), 8672, 2015.

8. HAN G., JIAYANG L., QUANQIU C., CUI Y., SHU B. Response of Soil Microbial Community to Application of Biochar in Cotton Soils with Different Continuous Cropping Years.” Scientific Reports. 7 (1), 10184, 2017.

9. CHEN Y., REN C.G., YANG B., PENG Y., DAI C.C. Priming efects of the endophytic fungus Phomopsis liquidambari on soil mineral $\mathrm{N}$ transformation. Microbial Ecology. 65, 161, 2013.

10. XU Z., MARTIN A.H., LARS H.H., SAMUEL J., SØREN J.S. Bioinformatic approaches reveal metagenomic characterization of soil microbial community. PLoS ONE 9 (4). e93445, 2014.

11. LAUBER C.L., STRICKLAND M.S., BRADFORD M.A., FIERER N. The influence of soil properties on the structure of bacterial and fungal communities across land-use types. Soil Biology and Biochemistry. 40, 2407, 2008

12. GIRVAN M.S., BULLIMORE J., PRETTY J.N., OSBORN A. M., BALL A.S. Soil type is the primary determinant of the composition of the total and active bacterial communities in arable soils. Applied Environmental Microbiology. 69, 1800, 2003.

13. JEONG M.K., AN-SUNG R., SEUNG-CHUL C., EUNJEONG K., MOON-TAE C., BYUNG-KOO A., SUNKUK K., YOUNG-HAN L., JAE-HO J., SEONG-SOO K., SHIN A.L., JAE-HYUNG A., JAEKYEONG S., HANG-YEON W. Soil $\mathrm{pH}$ and electrical conductivity are key edaphic factors shaping bacterial communities of greenhouse soils in Korea. Journal of Microbiology. 54, 838, 2016.

14. XIONG J., PENG F., SUN H., XUE X., CHU H. Divergent responses of soil fungi functional groups to short-term warming. Microbiol Ecology. 68, 708, 2014.

15. LAUBER C.L., HAMADY M., KNIGHT R., FIERER N. Pyrosequencing-based assessment of soil $\mathrm{pH}$ as a predictor of soil bacterial community structure at the continental scale. Applied Environmental Microbiology. 75, 5111, 2009.

16. CONGCONG S., JINBO X., HUAYONG Z., YOUZHI F., XIANGUI L., XINYU L., WENJU L., HAIYAN C. Soil $\mathrm{pH}$ drives the spatial distribution of bacterial communities along elevation on Changbai Mountain. Soil Biology and Biochemistry. 57, 204, 2013.

17. FERNANDO T.M., MANUEL D., THOMAS C.J., DAVID J.E., VICTORIA O., BEATRIZ G., JOSÉ L.Q., MIGUEL G., ANTONIO G., WERNER U., MATTHEW A.B., TULIO A., CLAUDIA B., DONALDO B., ADRIANA F., JUAN G., JULIO R.G., ELISABETH H., MOHAMMAD J., REBECCA L.M., MARIA M., KAMAL N., ABELARDO O., ILAN S., DELI W., NATASHA N.W., XIA Y., ELI Z., BRAJESH K. S. Increasing aridity reduces soil microbial diversity and abundance in global drylands. Proceedings of the National Academy of Sciences of the United States of America (PNAS). 112, 15684, 2015.

18. MA J., IBEKWE A.M., YANG C.H., CROWLEY D.E. Bacterial diversity and composition in major fresh produce growing soils affected by physiochemical properties and geographic locations. Science of the Total Environment. 564, 199, 2016.

19. LEFF J.W., STUART E.J., SUZANNE M.P., ALBERT B., ELIZABETH T.B., JENNIFER L.F.W. STANLEY H., SARAH E.H., KIRSTEN S.H., JOHANNES M.H. K., REBECCA L.M., KIMBERLY L.P., ANITA C.R., ERIC W.S., MARTIN S., CHRISTOPHER S., CARLY J.S., NOAH F. Consistent responses of soil microbial communities to elevated nutrient inputs in grasslands across the globe. Proceedings of the National Academy of Sciences of the United States of America (PNAS). 112, 10967, 2015.

20. PROBER S.M, LEFF J.W., BATES S.T., BORER E.T., FIRN J., HARPOLE W.S., et al. Plant diversity predicts beta but not alpha diversity of soil microbes across grasslands worldwide. Ecol Lett. 18, 85, 2015.

21. DYNARSKI K.A., HOULTON B.Z. Nutrient limitation of terrestrial free-living nitrogen fixation. New Phytol. 217, 1050, 2018.

22. MACDONALD C., SINGH B. Harnessing plantmicrobe interactions for enhancing farm productivity. Bioengineered. 5, 5, 2014.

23. POMMIER T., CANTAREL A.A.M., GRIGULIS K., LAVOREL S., LEGAY N., BAXENDALE C., BARDGETT R., BAHN M., POLY F., CLÉMENT J. C. The added value of including key microbial traits to determine nitrogen-related ecosystem services in managed grasslands. Journal of Applied Ecology. 55, 49, 2018.

24. LEHMANN J., JOSEPH S. Biochar for environmental management: an introduction. In: Lehmann, J., Joseph, S. (Eds.), Biochar for Environmental Management: Science and Technology. Earthscan, London, 1, 2009.

25. ATKINSON C.J., FITZGERALD J.D., HIPPS N.A. Potential mechanisms for achieving agricultural benefits from biochar application to temperate soils: a review. Plant and Soil. 337 (1-2), 1, 2010.

26. JINDO K., SÁNCHEZ-MONEDERO M. A., HERNÁNDEZ T., GARCÍA C., FURUKAWA T., MATSUMOTO K., BASTIDA, F. Biochar influences the microbial community structure during manure composting with agricultural wastes. Science of the Total Environment, 416, 476, 2012.

27. PIETIKÄINEN J., KIIKKILÄ O., FRITZE H. Charcoal as a habitat for microbes and its effect on the microbial 
community of the underlying humus. Oikos, 89 (2), 231, 2000.

28. THIES J.E., RILLIG M.C. Characteristics of biochar: biological properties. Biochar for environmental management: Science and Technology, 85, 2009.

29. SMITH J.L., COLLINS H.P., BAILEY V.L. The effect of young biochar on soil respiration. Soil Biology and Biochemistry, 42 (12), 2345, 2010.

30. LAMMIRATO C., MILTNER A., KAESTNER M. Effects of wood char and activated carbon on the hydrolysis of cellobiose by $\beta$-glucosidase from Aspergillus niger. Soil Biology and Biochemistry, 43 (9), 1936, 2011.

31. KASOZI G.N., ZIMMERMAN A.R., NKEDI-KIZZA P., GAO B. Catechol and humic acid sorption onto a range of laboratory-produced black carbons (biochars). Environmental science \& technology, 44 (16), 6189, 2010.

32. ZHONG W., TING G., WEI W., BIN Z., XIANGUI L., QIANRU H., WEISHOU S.The effects of mineral fertilizer and organic manure on soil microbial community and diversity. Plant and Soil. 326 (1-2), 511, 2010.
33. FONTAINEA S., HENAULT C., AAMOR A., BDIOUI N., BLOOR J.M.G., MAIRE V., MARY B., REVAILLOT S., MARON P. A Fungi mediate long term sequestration of carbon and nitrogen in soil through their priming effect. Soil Biology and Biochemistry. 43 (1), 86, 2011.

34. HANSON C., ALLISON S., BRADFORD M., WALLENSTEIN M., TRESEDER K. Fungal taxa target different carbon sources in forest soil. Ecosystems. 11, $1157,2008$.

35. CHRISTOPHER W.S., ANDREW P.M., DAVID A.L., STEVEN K.S. Seasonal Dynamics of Previously Unknown Fungal Lineages in Tundra Soils. Science 2003: 1359, 2003.

36. PERRONE G., SUSCA A., COZZI G., EHRLICH K., VARGA J., FRISVAD J.C., SAMSON R.A. Biodiversity of Aspergillus species in some important agricultural products. Studies in mycology. 59, 53, 2007.

37. ANDREW C., PROCTER J., CHRISTOPHER E., PHILIP A., FAY H., WAYNE P., ROBERT B. J. Fungal Community Responses to Past and Future Atmospheric $\mathrm{CO}_{2}$ Differ by Soil Type. Appl. Environ. Microbiol. 80 (23) 7364, 2014.

\section{Supplementary}

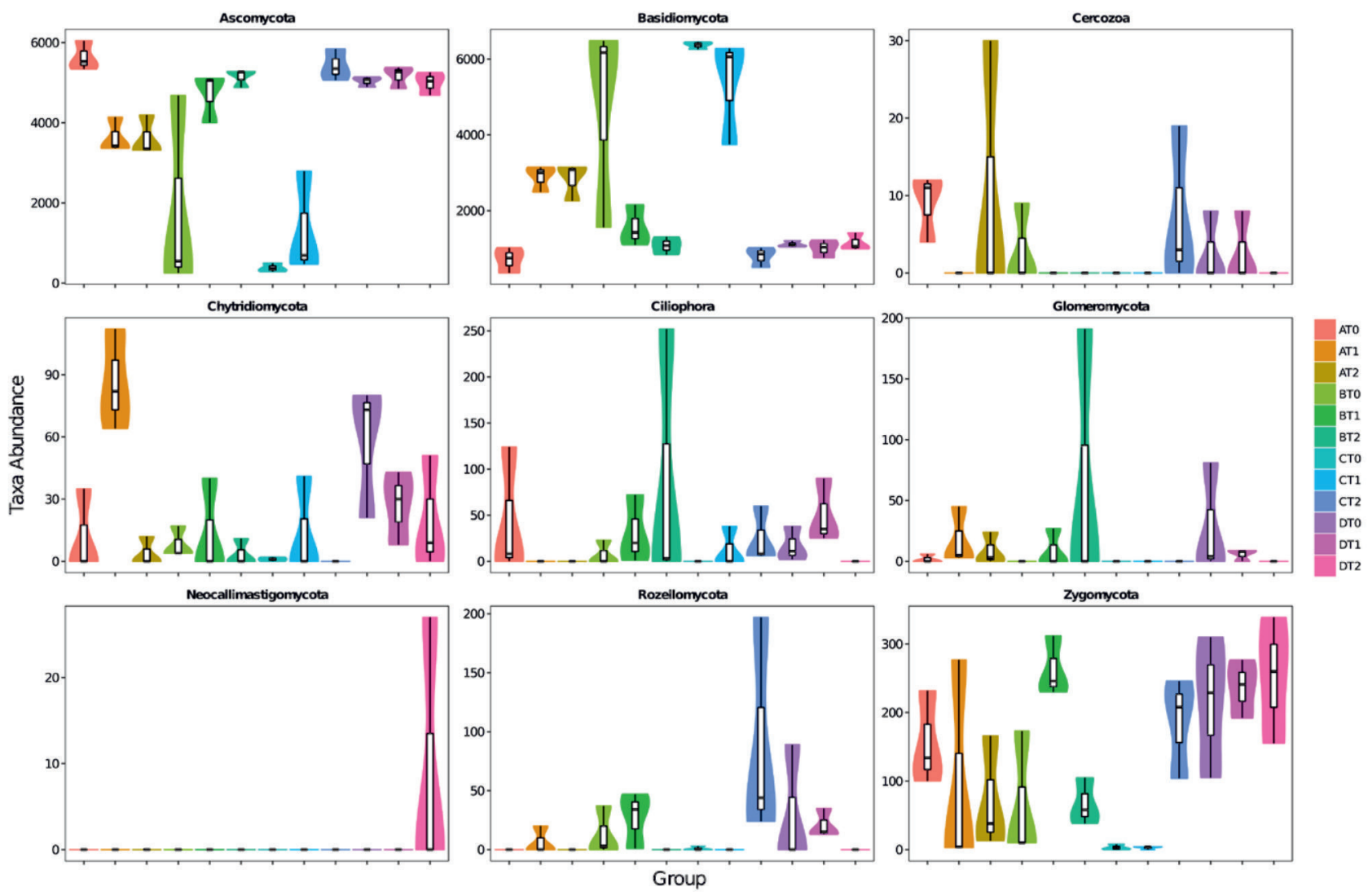

Fig. 1. The most dominant phyla across all the treatment groups. 